\title{
Very Early C-Reactive Protein Levels after Acute Myocardial Infarction Predict Early Outcome and Late Prognosis
}

\author{
Dawod Sharif ${ }^{1,2 *}$, Mahmoud Hammoud ${ }^{1}$, Amal Sharif-Rasslan ${ }^{2,3}$, Edward Abinader ${ }^{1}$, \\ Majed Odeh ${ }^{2,4}$ \\ ${ }^{1}$ Departments of Cardiology, Bnai Zion Medical Center, Haifa, Israel \\ ${ }^{2}$ Technion-Israel Institute of Technology, Haifa, Israel \\ ${ }^{3}$ The Academic Arab College, Mathematics Department, Haifa, Israel \\ ${ }^{4}$ Departments of Internal Medicine A, Bnai Zion Medical Center, Haifa, Israel \\ Email: ${ }^{*}$ dawod.sharif@b-zion.org.il
}

Received 29 November 2014; accepted 3 August 2015; published 6 August 2015

Copyright (C) 2015 by authors and Scientific Research Publishing Inc.

This work is licensed under the Creative Commons Attribution International License (CC BY). http://creativecommons.org/licenses/by/4.0/

c) (i) Open Access

\begin{abstract}
Objectives: C-reactive protein (CRP) blood levels are associated with atherosclerosis and increased incidence of coronary events. Aim: To evaluate the utility for risk stratification of very early blood CRP levels, during the first 6 hours after the onset of chest pain, in patients with acute myocardial infarction (AMI). Methods: 118 patients with AMI, 88 men, age $63.3 \pm 8$ yrs, were evaluated, and CRP was assessed within the first 6 hours after the onset of chest pains. Results: CRP level in all patients was $15.7 \pm 14.1 \mathrm{mg} / \mathrm{L}$. Its level increased with higher Killip class, $11.2 \pm 5 \mathrm{mg} / \mathrm{L}$ in class 1 , and $62 \pm 7 \mathrm{mg} / \mathrm{L}$ in class $4(\mathrm{p}<0.01)$, and with lower left ventricular ejection fraction (EF), $32.3 \pm 10 \mathrm{mg} / \mathrm{L}$ with $\mathrm{EF}<30 \%$ and $9 \pm 4 \mathrm{mg} / \mathrm{L}$ with $\mathrm{EF}>40 \%(\mathrm{p}<0.01)$. Higher CRP values were found in patients with 3 vessel coronary artery diseases $20.7 \pm 8 \mathrm{mg} / \mathrm{L}$, vs. $8.7 \pm 4 \mathrm{mg} / \mathrm{L}$ with 2 and 1 vessel disease $(p<0.05)$. Patients with in-hospital complications had higher CRP, $33.7 \pm 10$ $\mathrm{mg} / \mathrm{L}$ vs. $12.1 \pm 5 \mathrm{mg} / \mathrm{L}$ in those without $(\mathrm{p}<0.001)$. Eight patients died at one-year follow-up. The CRP levels on admission in patients who died during the first year of follow-up, $45.2 \pm 7.7 \mathrm{mg} / \mathrm{L}$ were higher than those in the survivors without adverse events, $11.6 \pm 5 \mathrm{mg} / \mathrm{L}(\mathrm{p}<0.001)$. Admission CRP level in patients re-admitted with unstable angina, re-infarction or those who had coronary bypass surgery was similar to that in those who were not. Conclusions: Very early blood CRP levels in patients with AMI predict functional capacity, systolic left ventricular function, extent of coronary artery disease, early and short term complications and 1-year mortality but not recurrent myocardial ischemic events.
\end{abstract}

\section{Keywords}

C-Reactive Protein, Myocardial Infarction, Prognosis, Coronary Artery Disease,

*Corresponding author.

How to cite this paper: Sharif, D., Hammoud, M., Sharif-Rasslan, A., Abinader, E. and Odeh, M. (2015) Very Early C-Reactive Protein Levels after Acute Myocardial Infarction Predict Early Outcome and Late Prognosis. International Journal of Clinical Medicine, 6, 547-553. http://dx.doi.org/10.4236/ijcm.2015.68073 


\section{Coronary Angiography}

\section{Introduction}

C-reactive protein (CRP), an acute phase reactant, is a marker of inflammatory activity and is associated with atherosclerosis and increased incidence of coronary events [1] [2]. Higher blood CRP levels are associated with increased risk in patients with unstable angina [3]-[6], and its levels increase during the early days after acute myocardial infarction (AMI) [7]. Very early, during the first hours after the onset of chest pain, CRP levels may reflect the process leading to coronary artery thrombosis and AMI. The purpose of this study was to assess the utility of very early CRP levels after acute myocardial infarction in risk stratification.

\section{Methods}

Population: One hundred and eighteen consecutive patients, aged $63.3 \pm 8$ years, with AMI admitted to the coronary care unit were included. AMI was defined as prolonged typical chest pain, typical electrocardiographic changes with ST segment elevation, development of Q waves or persistent new ST depression, and elevation of troponin I and the MB isoenzyme of creatinine kinase of the study group 88 were men, age $60.4 \pm 12$ years and 30 were women, age $71.9 \pm 7$ years $\mathrm{p}<0.05$.

Patient Characteristics: The risk factor profile of patients on admission included smoking in 52 (44\%), hyperlipidemia in 51 (43.2\%), hypertension in $63(53.4 \%)$, obesity in 31 (26.3\%), previous MI in $34(28.8 \%)$, family history of coronary artery disease in $25(21.2 \%)$, diabetes mellitus in $29(24.6 \%)$ and peripheral vascular disease (PVD) in 15 (12.7\%).

At presentation, AMI with ST-segment elevation (STEMI) occurred in 71 patients $(60.2 \%), 69(97 \%)$ of them developed Q waves later, and 25 of them (35.2\%) had a history of angina pectoris. Fibrinolytic treatment was administered in 44 patients $(62 \%)$, while primary balloon angioplasty was performed in $16(23 \%)$.

Non-STEMI was diagnosed in 47 Patients (39.8\%), 31 (66\%) of them had a history of angina pectoris. Overall 49 patients had Non Q-wave AMI.

Blood levels of CRP were measured immediately on admission within 6 hours of the onset of chest pain. Turbidimetric immunoassay method was used to measure CRP levels. The study protocol conforms to the ethical guidelines of the Declaration of Helsinki.

Statistical Analysis: Parameters were expressed as mean \pm standard deviation or number (\%). Between-group comparisons were made using two-tailed Student t-test for continuous variables and Pearson $\chi^{2}$ test for categorical variables. $\mathrm{P}<0.05$ was considered statistically significant. All the analyses were done using SPSS version 13 software.

\section{Results}

Hospital arrival of the patients and measurement of blood levels of CRP averaged $3.71 \pm 1.2$ hours after the onset chest pain. Results of CRP were available within 15 minutes after taking the blood sample.

Patient Characteristics and CRP: Average CRP level was $15.7 \pm 14 \mathrm{mg} / \mathrm{L}$, and was higher in women $21.4 \pm$ $10 \mathrm{mg} / \mathrm{L}$ compared to men $13.8 \pm 7 \mathrm{mg} / \mathrm{L}(\mathrm{p}<0.01)$. No significant difference was found in CRP levels between STEMI, $15.3 \pm 8 \mathrm{mg} / \mathrm{L}$ and non-STEMI, $16.3 \pm 15 \mathrm{mg} / \mathrm{L}(\mathrm{p}=\mathrm{ns})$ (Table 1). Patients with recurrent-MI, pre-MI angina pectoris, smoking, hypertension and PVD were associated with higher CRP values compared to those without (Table 1). Levels of CRP were higher with increasing age, $26.6 \pm 11 \mathrm{mg} / \mathrm{L}$ (age $>75$ years), $15.6 \pm 8$ $\mathrm{mg} / \mathrm{L}$ (age 51 - 75 years) and $8.7 \pm 4.5 \mathrm{mg} / \mathrm{L}$ (age $30-50$ years), $(\mathrm{p}<0.05)$.

CRP Levels in Subclasses of Patients: Levels of CRP were higher in patients with higher Killip class (Table 2). The majority of the patients (75), were in class I with a CRP level of $11.2 \pm 5 \mathrm{mg} / \mathrm{L}$, and $22.7 \pm 8 \mathrm{mg} / \mathrm{L}$ in class II $(\mathrm{p}<0.01)$, while in classes III and IV CRP levels were much higher $27.2 \pm 4 \mathrm{mg} / \mathrm{L}$ and $62.7 \pm 4 \mathrm{mg} / \mathrm{L} \mathrm{compared}$ to classes I and II, respectively, ( $p<0.01$ for both); moreover, patients in class IV had significantly higher CRP levels than class III, $(\mathrm{p}<0.05)$.

CRP levels were higher in patients with lower LVEF. Higher CRP levels were also found in patients with 3 vessel coronary artery disease, $20.7 \pm 8 \mathrm{mg} / \mathrm{L}$, versus $8.7 \pm 4 \mathrm{mg} / \mathrm{L}$ in 2 and 1 vessel disease $(\mathrm{p}<0.01)($ Table 2$)$. 
Table 1. Patients characteristics, CRP (mg/L) and risk factors.

\begin{tabular}{ccccc}
\hline & \multicolumn{2}{c}{ Avarege CRP Levels (mg/L) } & & Non-STEMI \\
\hline All Patients & Men & Women & STEMI & $16.3 \pm 15$ \\
\hline $15.7 \pm 14$ & $13.8 \pm 7$ & $21.4 \pm 10^{*}$ & $15.3 \pm 8$ & Risk Absent \\
Re-MI & Number & $\mathbf{( \% )}$ & Risk Present & $13.5 \pm 4^{* *}$ \\
Pre-MI AP & 34 & 28.8 & $21 \pm 6$ & $9.9 \pm 5^{* *}$ \\
Smoking & 56 & 47.5 & $22.1 \pm 6$ & $14.3 \pm 4^{*}$ \\
Hypertension & 52 & 44.1 & $17.4 \pm 5$ & $12.4 \pm 3^{*}$ \\
Diabetes Mellitus & 63 & 53.4 & $18.6 \pm 4$ & $15.5 \pm 5$ \\
Hyperlipidemia & 29 & 24.6 & $17.4 \pm 4$ & $15.3 \pm 4$ \\
Statin & 51 & 43.2 & $16.2 \pm 5$ & $15.6 \pm 6$ \\
Obesity & 21 & 17.8 & $16.1 \pm 5$ & $16.3 \pm 7$ \\
Peripheral Vasular Disease & 31 & 26.3 & $14 \pm 6$ & $14.2 \pm 4^{* *}$ \\
Family History & 15 & 12.7 & $26 \pm 5$ & $15.6 \pm 6$
\end{tabular}

AP: Angina Pectoris; MI: Myocardial Infarction; STEMI: ST-elevation myocardial infarction; ${ }^{*}$ Statistically Significant $(\mathrm{p}<0.05)$; ${ }^{* *}$ Statistically Significant $(\mathrm{p}<0.01)$.

Table 2. CRP (mg/L) in clinical subgroups.

\begin{tabular}{|c|c|c|c|}
\hline & & No. (\%) & $\mathrm{CRP}(\mathrm{mg} / \mathrm{L})$ \\
\hline \multirow{4}{*}{$\begin{array}{l}\text { Killip } \\
\text { Class }\end{array}$} & I & $75(63.5)$ & $11.2 \pm 5$ \\
\hline & II & $23(19.5)$ & $22.7 \pm 8^{*}$ \\
\hline & III & $13(11)$ & $27.2 \pm 4^{*}$ \\
\hline & IV & $7(6)$ & $62.7 \pm 4^{*}$ \\
\hline \multirow{3}{*}{ LVEF (\%) } & $<30$ & $24(20)$ & $31.8 \pm 10$ \\
\hline & $30-39$ & $28(24)$ & $19 \pm 5^{*}$ \\
\hline & $>40$ & $66(56)$ & $10.1 \pm 4^{*}$ \\
\hline \multirow{3}{*}{ CAD } & $1 \mathrm{VD}$ & $31(36.5)$ & $8.6 \pm 7$ \\
\hline & $2 \mathrm{VD}$ & $24(28.2)$ & $8.7 \pm 4$ \\
\hline & $3 \mathrm{VD}$ & $30(35.3)$ & $25.9 \pm 8^{*}$ \\
\hline
\end{tabular}

CAD: Coronary Artery Disease; LVEF: Left Venticular Ejection Fraction; ${ }^{*}$ Statistically Significant $(\mathrm{p}<0.05)$.

Prediction Power of Very Early CRP Levels: Most of the patients with CRP levels lower than $5 \mathrm{mg} / \mathrm{L}$ were in Killip class 1, while higher levels of CRP were associated with higher Killip class (Table 3).

Most of the patients with CRP levels less than $5 \mathrm{mg} / \mathrm{L}$, had LVEF above $40 \%$, while higher CRP levels were associated with lower LVEF (Table 3).

Eighty five patients had coronary arteriography, most of those with CRP less than $5 \mathrm{mg} / \mathrm{L}$ had one vessel disease while higher CRP levels were associated with 3 vessel disease (Table 3).

Ranges of CRP as Predictor of Mortality and Morbidity: Patients with cardiovascular events during the first month of MI had higher CRP blood levels (Table 4). In Table 5, CRP blood level ranges are described as a predictor of early and late events. It can be seen that higher CRP blood levels predicted early and short term complications and one year mortality but not recurrent myocardial ischemic events. 
Table 3. Ranges of CRP levels as predictor of function and extent of coronary disease.

\begin{tabular}{|c|c|c|c|c|c|c|}
\hline \multicolumn{2}{|c|}{$\mathrm{CRP}(\mathrm{mg} / \mathrm{L})$} & $<5$ & $5-10$ & $11-35$ & $>35$ & $>10$ \\
\hline \multicolumn{2}{|c|}{ No. of Patients } & 34 & 23 & 46 & 15 & 61 \\
\hline \multirow{4}{*}{ 雬 } & $\mathbf{I}$ & $30(88.2)$ & $17(74)$ & $26(56.5)$ & $2(13.3)^{*}$ & $28(45.9)$ \\
\hline & II & $4(11.8)$ & $3(13)$ & $10(21.7)$ & $6(40)^{*}$ & $16(26.2)$ \\
\hline & III & $0^{*}$ & $3(13)$ & $7(15.3)$ & $3(20)$ & $10(16.4)$ \\
\hline & IV & $0^{*}$ & $0^{*}$ & $3(6.5)$ & $4(26.7)$ & $7(11.5)$ \\
\hline \multirow{3}{*}{ 䖝 } & $>40 \%$ & $30(88.2)$ & $15(65.2)$ & $18(39.1)^{*}$ & $3(20)^{*}$ & $21(34.4)$ \\
\hline & $30 \%-39 \%$ & $4(11.8)$ & $4(17.4)$ & $18(39.1)^{*}$ & $2(13.3)$ & $20(32.8)$ \\
\hline & $<30 \%$ & 0 & $4(17.4)$ & $10(21.8)$ & $10(66.7)^{*}$ & $20(32.8)^{*}$ \\
\hline \multicolumn{2}{|c|}{ No. of Patients with CA } & 28 & 18 & 32 & 7 & 39 \\
\hline \multicolumn{2}{|c|}{ 1VD } & 15 (53.6) & 7 (38.9) & $8(25)$ & $1(14.3)^{*}$ & $9(23.1)$ \\
\hline \multicolumn{2}{|c|}{ 2VD } & $10(35.7)$ & $7(38.9)$ & $7(21.9)$ & 0 & $7(17.9)$ \\
\hline \multicolumn{2}{|c|}{ 3VD } & $3(10.7)$ & $4(22.2)$ & $17(53.1)^{*}$ & $6(85.7)^{*}$ & $23(59)^{*}$ \\
\hline
\end{tabular}

CA: Coronary Angiography; 1VD, 2VD, 3VD: number of coronary vessels diseased; Percent between brackets; "Statistically Significant ( $p<0.05)$.

Table 4. CRP (mg/L) in patients with complications.

\begin{tabular}{cccccc}
\hline & Death & Shock & AP & Re-MI & Event Free \\
\hline $\mathbf{1 M}$ & $31 \pm 4.6^{\dagger}$ & $39.6 \pm 4.7^{\dagger}$ & $28.3 \pm 5.8^{\dagger}$ & $20.8 \pm 4.8^{\dagger}$ & $11.8 \pm 4.8$ \\
$\mathbf{1 M - 1 Y r}$ & $45.2 \pm 7.7^{\dagger}$ & ------- & $13.25 \pm 5$ & $11.6 \pm 2.1$ & $11.6 \pm 5$ \\
\hline
\end{tabular}

AP: Angina Pectoris; MI: Myocardial Infarction; IM: one month; IYr: one year; ${ }^{\dagger}$ Statistically Significant Compared to Event Free.

Table 5. Range of CRP concentrations and cardiac events.

\begin{tabular}{|c|c|c|c|c|c|}
\hline \multicolumn{2}{|c|}{ CRP Range } & $<\mathbf{5}$ & $5-10$ & $11-35$ & $>35$ \\
\hline \multicolumn{2}{|c|}{ No. of Patients } & 34 & 23 & 46 & 15 \\
\hline \multirow{5}{*}{1 Month Events } & AP (\%) & 0 & 4.3 & 10.9 & $20^{*}$ \\
\hline & Re-MI (\%) & 2.9 & 4.3 & 8.7 & 6.7 \\
\hline & AP+RE-MI (\%) & 29.9 & 8.6 & 19.6 & 26.7 \\
\hline & Shock $(\%)$ & 0 & 0 & 6.5 & $33.3^{*}$ \\
\hline & Death $(\%)$ & 0 & 4.3 & 10.9 & $33.3^{*}$ \\
\hline \multirow{4}{*}{$\begin{array}{l}1 \text { Month to } \\
1 \text { Year } \\
\text { Events }\end{array}$} & Re-MI (\%) & 8.8 & $30.4^{*}$ & 17.4 & 17.4 \\
\hline & Revascularization (\%) & 11.8 & 8.7 & 8.7 & 6.7 \\
\hline & Death (\%) & 0 & 4.3 & 2.2 & $40^{*}$ \\
\hline & All Events (\%) & 20.6 & 43.4 & 28.3 & 46.7 \\
\hline \multirow{3}{*}{$\begin{array}{c}\text { MI Onset to } 1 \text { Year } \\
\text { Events }\end{array}$} & Re-MI (\%) & $11.7^{*}$ & 34.7 & 26.1 & 24.1 \\
\hline & Revascularization (\%) & 11.8 & 8.7 & 8.7 & 6.7 \\
\hline & Death (\%) & 0 & 8.6 & 13.1 & $73.3^{*}$ \\
\hline
\end{tabular}

AP: Angina Pectoris; Re-MI: Recarnt Myocardial Infarction; "Statistically Significant $(\mathrm{p}<0.05)$. 


\section{Discussion}

In this study very early ( $3.71 \pm 1.2$ hours of onset of chest pain) CRP blood levels in patients with AMI, predicted functional capacity, LVEF, extent of coronary artery disease, early and short term complications and one year mortality but not recurrent myocardial ischemic events or interventions.

AMI is associated with an increase in inflammatory markers. Thus, elevation of white blood cell count develops within 2 hours after chest pain, and reaches peak 2 - 4 days after AMI. Worse angiographic appearances of culprit lesions in patients with acute coronary syndromes with higher white blood cell counts were reported [8] [9]. The erythrocyte sedimentation rate is normal during the first 2 days after AMI, even though fever and leukocytosis may be present and reaches a peak on the fourth to fifth day, and may remain elevated for several weeks, but the peak does not correlate with the size of infarction or prognosis [10] [11]. In a study about the kinetics of CRP release in different forms of acute coronary syndrome, peak CRP appeared after 49 hours of onset of chest pain, and later in patients with STEMI [12]. In another work studying serial CRP levels, multiple logistic regression analysis identified only early CRP level after AMI as predictor of unfavorable outcome [13]. In patients with STEMI, elevated CRP is associated with worse angiographic appearance and higher risk to develop heart failure [14] [15]. In a study of serial CRP levels, multiple logistic regression analysis revealed that peak CRP was an independent predictor of development of mitral regurgitation after AMI [16]. Absence of a significant relation between baseline CRP levels and extent of atherosclerosis on coronary angiography in patients with unstable angina was reported; however, both CRP level and atherosclerosis extent were associated with worse outcome after 6 months [17].

CRP levels are related to the stable atherosclerotic process without acute coronary syndrome, but at lower concentrations and thus high sensitivity CRP assays are necessary for evaluation. Several days after AMI, CRP levels are high as a result of the MI. The CRP levels in this study, very early after the onset of chest pain and MI, are higher than the high sensitivity CRP related to stable atherosclerosis. The CRP levels in our study may reflect the intensity of the process immediately before and accompanying the acute coronary thrombosis and MI.

Measurement of cardiac biomarker levels is routinely applied in patients with AMI in order to estimate the extent of myocardial necrosis. Creatine phospokinase (CPK) and the MB isoenzyme blood concentrations were used to estimate infarct size [18]. Troponin blood levels replaced CPK in the evaluation of patients with acute coronary syndrome [19]. Several studies reported that a single measurement of troponin T and I 72 to $96 \mathrm{~h}$ after myocardial infarction provided an estimate of infarct size [20]-[23]. Thus, all these myocardial biomarkers need a long period of time in order to estimate the extent of myocardial damage. In contrast to the studies mentioned above, in the present study, very early CRP blood levels, which can be obtained several minutes after hospital arrival and blood sampling provide very early and rapid estimate of infarct size and prognosis. Thus, very early measurement of CRP blood levels, provide an additional useful and rapid tool in the clinical armamentarium for risk stratification in patients presenting with acute coronary syndrome and AMI.

\section{Conclusion}

In conclusion, very early CRP blood levels may aid in risk stratification of patients with acute coronary syndrome, and in patients with AMI may predict Killip class, systolic LV function, extent of coronary disease, early and short term complications, and one-year mortality but not recurrent myocardial ischemic events.

\section{Competing Interest}

The authors have declared that no competing interest exists.

\section{References}

[1] Ridker, P.M., Cushman, M., Stampfer, M.J., Tracy, R.P. and Hennekens, C.H. (1997) Inflammation, Aspirin and the Risk of Cardiovascular Disease in Apparently Healthy Men. The New England Journal of Medicine, 336, 973-979. http://dx.doi.org/10.1056/NEJM199704033361401

[2] Ridker, P.M., Buring, J.E., Shih, J. and Hennekens, C.H. (1998) Prospective Study of C-Reactive Protein and the Risk of Future Cardiovascular Events among Apparently Healthy Women. Circulation, 98, 731-733. http://dx.doi.org/10.1161/01.CIR.98.8.731

[3] Liuzzo, G., Biasucci, L.M., Gallimore, J.R., et al. (1994) The Prognostic Value of C-Reactive Protein and Serum 
Amyloid A Protein in Severe Unstable Angina. The New England Journal of Medicine, 331, 417-424. http://dx.doi.org/10.1056/NEJM199408183310701

[4] Morrow, D.A., Rifai, N., Antman, E.M., et al. (1998) C-Reactive Protein Is a Potent Predictor of Mortality Independently and in Combination with Troponin T in Acute Coronary Syndromes: A TIMI 11A Substudy. Journal of the American College of Cardiology, 31, 1460-1465. http://dx.doi.org/10.1016/S0735-1097(98)00136-3

[5] Ferreiros, E.R., Boissonnet, C.P., Pizzaro, R., et al. (1999) Independent Prognostic Value of Elevated C-Reactive Protein in Unstable Angina. Circulation, 100, 1958-1963. http://dx.doi.org/10.1161/01.CIR.100.19.1958

[6] Biasucci, L.M., Liuzzo, G., Grillo, R.L., et al. (1999) Elevated Levels of C-Reactive Protein at Discharge in Patients with Unstable Angina Predict Recurrent Instability. Circulation, 99, 855-860. http://dx.doi.org/10.1161/01.CIR.99.7.855

[7] Pietila, K.O., Harmoineni, A.P., Jokiniittyf, J. and Pasternack, A.I. (1996) Serum C-Reactive Protein Concentration in Acute Myocardial Infarction and Its Relationship to Mortality during 24 Months of Follow-Up in Patients under Thrombolytic Treatment. European Heart Journal, 17, 1345-1349. http://dx.doi.org/10.1093/oxfordjournals.eurheartj.a015068

[8] Sabatine, M.S., Morrow, D.A., Cannon, C.P., et al. (2002) Relationship between Baseline White Blood Cell Count and Degree of Coronary Artery Disease and Mortality in Patients with Acute Coronary Syndromes: TACTICS TIMI 18 (Treat Angina with Agrastat and Determine Cost of Therapy with an Invasive or Conservative Strategy-Thrombolysis in Myocardial Infarction Trial) Substudy. Journal of the American College of Cardiology, 40, 1761-1768. http://dx.doi.org/10.1016/S0735-1097(02)02484-1

[9] Barron, H.V., Cannon, C.P., Murphy, S.A., Braunwald, E. and Gibson, M. (2000) Association between White Blood Cell Count, Epicardial Blood Flow, Myocardial Perfusion and Clinical Outcomesin the Setting of Cute Myocardial Infarction. A Thrombolysis in Myocardial Infarction Substudy. Circulation, 102, 2329-2334. http://dx.doi.org/10.1161/01.CIR.102.19.2329

[10] Timmer, J.R., Ottervanger, J.P., Hoorntje, J.C., et al. (2005) Prognostic Value of Erythrocyte Sedimentation Rate in ST Segment Elevation Myocardial Infarction: Interaction with Hyperglycaemia. Journal of Internal Medicine, 257, 423429. http://dx.doi.org/10.1111/j.1365-2796.2005.01478.x

[11] Fatih Ozlu, M., Sen, N., Fatih Karakas, M., Turak, O., Ozcan, F., Kanat, S., et al. (2012) Erythrocyte Sedimentation Rate in Acute Myocardial Infarction as a Predictor of Poor Prognosis and Impaired Reperfusion. Medicinski Glasnik, 9, 189-197.

[12] Sánchez, P.L., Rodríguez, M.V., Villacorta, E., Albarrán, C., Cruz, I., Moreiras, J.M., et al. (2006) Kinetics of CReactive Protein Release in Different Forms of Acute Coronary Syndrome. Revista Española de Cardiología, 59, 441447. http://dx.doi.org/10.1016/s1885-5857(06)60792-5

[13] Dimitrijevic, O., Stojcevski, B.D., Ignjatovic, S. and Singh, N.M. (2006) Serial Measurements of C-Reactive Protein after Acute Myocardial Infarction in Predicting One-Year Outcome. International Heart Journal, 47, 833-842. http://dx.doi.org/10.1536/ihj.47.833

[14] Berton, G., Cordiano, R., Palmieri, R., Pianca, S., Pagliara, V. and Palatini, P. (2003) C-Reactive Protein in Acute Myocardial Infarction: Association with Heart Failure. American Heart Journal, 145, 1094-1101. http://dx.doi.org/10.1016/S0002-8703(03)00098-X

[15] Sano, T., Tanaka, A., Namba, M., Nishibori, Y., Nishida, Y., Kawarabayashi, T., et al. (2003) C-Reactive Protein and Lesion Morphology in Patients with Acute Myocardial Infarction. Circulation, 108, 282-285. http://dx.doi.org/10.1161/01.CIR.0000079173.84669.4F

[16] Khno, T., Anzai, T., Naito, K., Ohno, Y., Kaneko, H., Li, H.-C., et al. (2007) Impact of Serum C-Reactive Protein Elevation on the Left Ventricular Spherical Change and the Development of Mitral Regurgitation after Anterior Acute Myocardial Infarction. Cardiology, 107, 386-394. http://dx.doi.org/10.1159/000099057

[17] Niccoli, G., Biasucci, L.M., Biscione, C., Fusco, B., Porto, I., Leone, A.M., et al. (2008) Independent Prognostic Value of C-Reactive Protein and Coronary Artery Disease Extent in Patients Affected by Unstable Angina. Atherosclerosis, 196, 779-785. http://dx.doi.org/10.1016/j.atherosclerosis.2007.01.009

[18] Hackel, D.B., Reimer, K.A., Ideker, R.E., Mikat, E.M., Hartwell, T.D., Parker, C.B., et al. (1984) Comparison of Enzymatic and Anatomic Estimates of Myocardial Infarct Size in Man. Circulation, 70, 824-835. http://dx.doi.org/10.1161/01.CIR.70.5.824

[19] Turer, A.T., Mahaffey, K.W., Gallup, D., Weaver, W.D., Christenson, R.H., Every, N.R. and Ohman, E.M. (2005) Enzyme Estimates of Infarct Size Correlate with Functional and Clinical Outcomes in the Setting of ST-Segment Elevation Myocardial Infarction. Current Controlled Trials in Cardiovascular Medicine, 6, 12. http://dx.doi.org/10.1186/1468-6708-6-12

[20] Licka, M., Zimmermann, R. and Zehelein, J. (2002) Troponin T Concentrations 72 Hours after Myocardial Infarction 
as a Serological Estimate of Infarct Size. Heart, 87, 520-524. http://dx.doi.org/10.1136/heart.87.6.520

[21] Steen, H., Giannitsis, E., Futterer, S., Merten, C., Juenger, C. and Katus, H.A. (2006) Cardiac Troponin T at 96 Hours after Acute Myocardial Infarction Correlates with Infarct Size and Cardiac Function. Journal of the American College of Cardiology, 48, 2192-2194. http://dx.doi.org/10.1016/j.jacc.2006.06.002

[22] Giannitsis, E., Steen, H., Kurz, K., Ivandic, B., Simon, A.C., Futterer, S., et al. (2008) Cardiac Magnetic Resonance Imaging Study for Quantification of Infarct Size Comparing Directly Serial versus Single Time-Point Measurements of Cardiac Troponin T. Journal of the American College of Cardiology, 51, 307-314. http://dx.doi.org/10.1016/j.jacc.2007.09.041

[23] Chia, S., Senatore, F., Raffel, O.C., Lee, H., Wackers, F.J.T. and Jang, I.-K. (2008) Utility of Cardiac Biomarkers in Predicting Infarct Size, Left Ventricular Function, and Clinical Outcome after Primary Percutaneous Coronary Intervention for ST-Segment Elevation Myocardial Infarction. JACC: Cardiovascular Interventions, 1, 415-423. http://dx.doi.org/10.1016/j.jcin.2008.04.010 